\title{
Study Based on the Early Mathematical Ability of Elementary Student Self-efficacy through the Concrete-Pictorial-Abstract Approach
}

\author{
Aan Yuliyanto*, Turmudi \\ Primary Education Study Program, School of Postgraduate Studies, Universitas Pendidikan Indonesia, Bandung 40154, Indonesia
}

Received July 27, 2020; Revised September 28, 2020; Accepted October 19, 2020

\section{Cite This Paper in the following Citation Styles}

(a): [1] Aan Yuliyanto, Turmudi , "Study Based on the Early Mathematical Ability of Elementary Student Self-efficacy through the Concrete-Pictorial-Abstract Approach," Universal Journal of Educational Research, Vol. 8, No. 11B, pp. 5901 - 5912, 2020. DOI: 10.13189/ujer.2020.082224.

(b): Aan Yuliyanto, Turmudi (2020). Study Based on the Early Mathematical Ability of Elementary Student Self-efficacy through the Concrete-Pictorial-Abstract Approach. Universal Journal of Educational Research, 8(11B), 5901 - 5912. DOI: 10.13189/ujer.2020.082224.

Copyright $@ 2020$ by authors, all rights reserved. Authors agree that this article remains permanently open access under the terms of the Creative Commons Attribution License 4.0 International License

\begin{abstract}
Self-efficacy (SE) can encourage students to complete their assignments. The research intended to investigate the achievement of students' self-efficacy by guiding concrete-pictorial-abstract (CPA) based on early mathematical ability (EMA). The research utilized quasi-experimental methods in learning mathematics regarding the volume of cubes and rectangular prisms. The population were all fifth-grade students of elementary schools in Purwakarta, Subang, Karawang, and Bekasi. Samples were 119 participants in Karawang. The instruments applied were questionnaires, tests, and daily journals. The prerequisite materials related to the volume of cubes and rectangular prisms are a topic about arithmetic calculation, square root, flat area, unit length, and problem-solving. Study's result informed that there was no significant difference in the achievement of students' self-efficacy through CPA and conventional mentoring in the high and moderate EMA groups. There was a significant difference in the achievement of students' self-efficacy in the low group given CPA and conventional guidance. This finding gave birth to a strategy of developing self-efficacy in elementary schools using the CPA approach, especially the use of concrete objects around students through mentoring activities in schools, considering that self-efficacy makes it easy to solve problems especially when it comes to students with low initial abilities.
\end{abstract}

Keywords Self-efficacy, Early Mathematical Ability,
Concrete-Pictorial-Abstract

\section{Introduction}

Self-efficacy is a part of the affective aspects that significantly influence learning. SE directs people to succeeding while promotes skill development, and self-confidence [1]. SE directs students to believe in their potential in facing the challenges of learning [2]. SE helps students make choices, will to progress, and diligently complete their obligations [3]. Individuals with high SE will be more comfortable adapting to academic life and can live more functional lives in the future [4]. They will not consider the task to be a challenge and threat with a sense of SE. When they have difficulty doing a task, they will recover their sense of SE and they will spend more effort and try to do their best to complete the task [5]. Students with good self-efficacy will show fluency in completing their assignments even though students found difficulties in their assignments. The reason is that SE greatly influences people's choices, the energy they exert, and their determination to face challenges [6].

But the learning situation is still limited in developing SE. The results of the SE interviews of Grade VII students revealed that SE students were still low. The reason was 
for additional foreign lessons, subjects that never had been encountered by students previously [7]. SE students are still low on subjects with an unpleasant learning atmosphere and motivate active learning. Students should be actively involved by giving freedom to present ideas with their peers. Learning outcomes on student work seem hesitant to write completion steps. This is the reason why SE students are low [8]. But, direct observations of fifth-grade elementary school students showed less courage to appear in public and then cried, despite the extraordinary academic potential.

Learning that also develops SE is mathematics. The purpose of mathematics required students to have a behavior that respects mathematical functions in life, curious, persistent, and confident in solving problems [9]. Mathematics learning has compulsory components for students to develop, one of which is a productive disposition, namely the desire to be skilled in assessing rational, useful, perseverance, and SE mathematics [10]. SE must be a concern for mathematics learning, thus mathematics achievement will easily increase [11]. If students' SE is continuously ignored, mathematics will be considered a difficult lesson [12]. The study said students are afraid of mathematics because the way they understand the material is not appropriate, especially at the beginning of the lesson [13]. The capacity of SE to promote students' better performance in mathematics highlights the importance of measuring and ensuring mathematics problem-solving efficacy among students [14]. The meaning of self-efficacy is one's belief in facing a given challenge. Accordingly, the development of the SE must be planned in learning. Likewise, SE development through four sources, namely personal success experience, the experience of others' success, persuasion through speech, and psychological conditions [15]. Roles and planning from a teachers are needed to build SE students [16]. Thus, guidance is needed that elevates the active and contextual role.

The CPA approach is defined as learning through a concrete stage by replacing objects directly, drawing objects directly, and during the final notation stage they were copied to an abstract like the actual mathematical paradigm [17]. The CPA approach at the concrete and pictorial stages provide familiarity in learning. The essence of the CPA approach is guidance in learning which consists of concrete stages giving opportunities to manipulate learning objects, pictorial stages of students having a bridge to visualize topics, and abstract stages as the core of mathematics learning that utilizes symbols. The CPA approach to the learning process tries to create as close as possible to the student or the child's real life, in this case, the concrete and pictorial process, in accordance to Piaget's theory, namely at the concrete operational level. The concrete stage is, in accordance to Piaget's theory, 7-11 years old children, is in the concrete operational stage where children develop direct observations that required mental manipulation of context problems [18]. This level is the beginning of rational reasoning. Students have logical operations that are applied to concrete objects [19]. Through a concrete stage in CPA learning which is a manipulative aspect as a source of benefits that makes students happy to be active in imagining the objects they are learning in real terms, these manipulative objects will improve students' dispositions and attitudes towards learning Cooper [20]. Learning will be effective if students are cheerful. Also, excitement in learning has been shown to have an extraordinary effect on the learning outcomes of students. [21]. It is reputable that pleasure is a factor of self-efficacy on the psychological index aspect. The pictorial phase provides the opportunity for imagination to represent concrete objects, which of course students love to draw. Happiness develops the psychological status of students. Happiness in learning, impacts students pursuing their dreams and talents, rather than understanding knowledge [22]. The three stages of the CPA approach provide opportunities in interacting with friends and teachers. This process stimulates students to understand the competencies of friends and generate SE through the persuasion of the teacher through the greeting and experiences of a friend's success. The study said that representative experience was the dominant factor of $\mathrm{SE}$ in each of the students' initial ability criteria [23]. Based on this description, the CPA approach is considered to increase student self-efficacy due to CPA that can create more meaningful learning for students through its concrete and pictorial phases. The abstract stage will train the SE aspects of students' personal experiences through exercises with abstract symbols. Verbal persuasion will build up when the teacher strengthens verbally in the pictorial process. Related to this, the study reveals that self-efficacy is learned through four main sources, namely the experience of success or experience of mastery (mastery experience), other people's experiences or social modeling (vicarious experience), verbal persuasion or social persuasion (verbal persuasion), and psychological conditions or physical and emotional (psychological index), where students try themselves and feel that they can do it [1]. Self-efficacy was one of the affective domains. Through a lesson or instruction will have an impact on the student's attitude. The research said that learning services provide personal experiences, where students can make a difference through service; we should expect that there will be a positive effect on their self-concept attitudes [24]. Furthermore, students who are motivated during the learning process affect their attitudes while participating in learning activities including increasing curiosity [25]. Conventional learning that is used in control classroom is teacher-centered while using the lecture method [26]. Other opinions defining the conventional approach are the teacher explaining the concept, allowing students to ask questions, showing problem-solving, giving practice, students writing answers, 
commenting on students' answers, and giving homework [27]. The meaning of conventional counseling is the activities that teachers do in making learning effective such as question and answer, lecturing, and writing learning in books. This study aimed to find out whether there are differences in the achievement of SE elementary school students in CPA learning and conventional learning in terms of EMA classification. EMA serves to classify students' abilities fairly and equally based on prerequisite knowledge of the next taught topic. The reason for classifying EMA is because students have different intellectuals. Thus, the students' self-ability findings with their respective prerequisite knowledge will be generated, namely high, medium, and low.

\section{Materials and Methods}

The research applied a quasi-experiment. Nonequivalent Control group design is the design of this study. The population is elementary school students in Purwakarta, Subang, Karawang, and Bekasi. The technique used to determine the sample was the sample aims. This sample of fifth-grade students involve four classes at the Elementary School in Karawang numbered 119 students. This EMA intends to see the EMA equivalence of students between the experimental group, namely the group of students who get learning with the CPA approach, and the control group, namely the group of students who get conventional learning. Based on the results of the overall EMA test for the two research groups, students are classified into three criteria for Early
Mathematics Ability (EMA), namely high, medium, and low EMA criteria. Based on the complete criteria data obtained, including the maximum score, mean, and standard deviation. The results of the EMA tests for both groups are presented in Table 1.

Table 1. Student EMA Group Criteria

\begin{tabular}{|c|c|c|}
\hline Maximum score & EMA Score Interval & $\begin{array}{c}\text { EMA Group } \\
\text { Criteria }\end{array}$ \\
\hline \multirow{3}{*}{20} & $x \geq 13$ & High \\
\cline { 2 - 3 } & $2<x<13$ & Medium \\
\cline { 2 - 3 } & $x \leq 2$ & Low \\
\hline
\end{tabular}

The instruments consisted of test questions to measure EMA, a questionnaire to measure SE, and student journals related to the impression of mentoring. 24 statements from four aspects were used in measuring students' self-efficacy after testing the validity and reliability of the instrument. Besides, analysis using the average difference test through SPSS version 25. The research process was carried out in three stages, namely preliminary, implementation, and presentation. The preliminary stage includes identification of problems related to SE of elementary school students who are still limited, preparation of problem-solving plans, preparation and testing of instruments, student equivalence testing to determine student EMA. The next stage is the implementation of the research with the initial scale test, providing treatment in the experimental and control classes, then the final scale test by presenting findings and analysis as well as conclusions and recommendations. To clarify, a schematic of the research procedure is being presented in Figure 1:

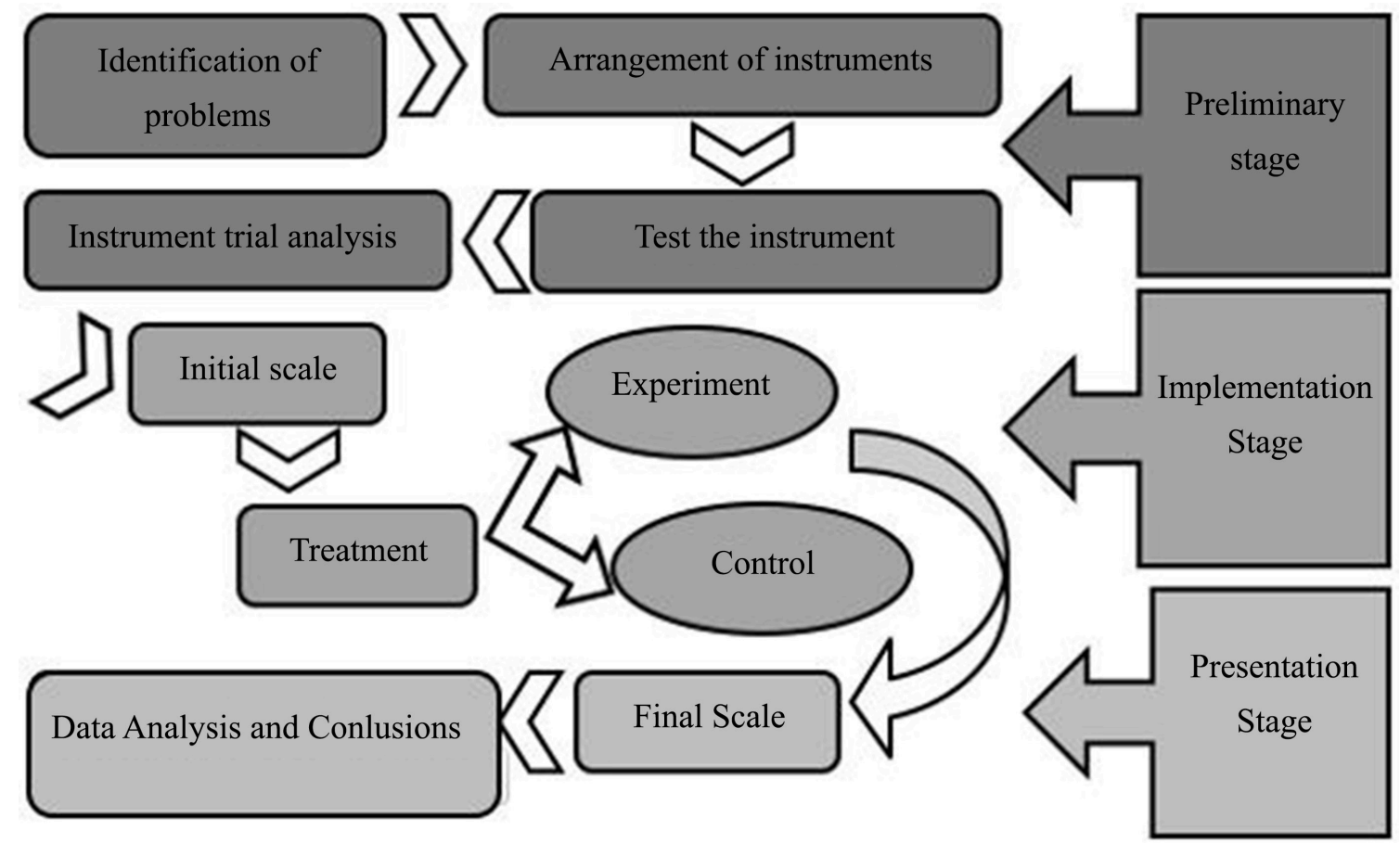

Figure 1. Research Procedure Scheme 
The following is an example of a blueprint for the questionnaire instrument used to measure SE as shown in Table 2:

Table 2. Self-efficacy Questionnaire Blueprint

\begin{tabular}{|c|c|c|}
\hline Aspects & Indicators & Statements \\
\hline \multirow{5}{*}{$\begin{array}{l}\text { 1. Mastery } \\
\text { Experience }\end{array}$} & \multirow{2}{*}{$\begin{array}{l}\text { A. Confident of being able to } \\
\text { complete difficult tasks }\end{array}$} & $\begin{array}{l}\text { 1. I find it difficult to imagine the geometric shape of space or a particular object if I } \\
\text { have never seen the object directly }\end{array}$ \\
\hline & & $\begin{array}{l}\text { 2. I am nervous about answering questions about building materials that are poorly } \\
\text { understood }\end{array}$ \\
\hline & \multirow{2}{*}{$\begin{array}{l}\text { B. Confident in completing } \\
\text { different tasks }\end{array}$} & $\begin{array}{l}\text { Learning mathematics using concrete objects (pencil cases, rubrics, and other } \\
\text { box-shaped objects), wastes time studying }\end{array}$ \\
\hline & & $\begin{array}{l}\text { 4. Observing directly concrete objects (pencil cases, rubrics, and other box-shaped } \\
\text { objects) makes it easier for me to draw pictures of these objects }\end{array}$ \\
\hline & $\begin{array}{l}\text { C. Confident of completing } \\
\text { challenging assignments }\end{array}$ & $\begin{array}{l}\text { 5. When I come across a challenging room building problem, I don't feel calm until I } \\
\text { can solve it }\end{array}$ \\
\hline \multirow{5}{*}{$\begin{array}{l}\text { 2. Vicarious } \\
\text { Experience }\end{array}$} & $\begin{array}{l}\text { A. Confident of being able to } \\
\text { complete difficult tasks if } \\
\text { others can }\end{array}$ & $\begin{array}{l}\text { 6. If one of my classmates can solve the volume-building problem, then I think that I } \\
\text { can also solve it. }\end{array}$ \\
\hline & \multirow{2}{*}{$\begin{array}{l}\text { B. Confident of being able to } \\
\text { complete different tasks if } \\
\text { other people are able }\end{array}$} & $\begin{array}{l}\text { 7. I can make mathematical calculations to solve mathematical problems with story } \\
\text { problems if I study with friends who are good at math. }\end{array}$ \\
\hline & & $\begin{array}{l}\text { 8. I am lazy to discuss with friends whose discussion discussions do not discuss } \\
\text { class lessons. }\end{array}$ \\
\hline & \multirow{2}{*}{$\begin{array}{l}\text { C. Confident of being able to } \\
\text { complete challenging tasks } \\
\text { when others can complete } \\
\text { them }\end{array}$} & $\begin{array}{l}\text { 9. I easily understand the web material, and, the volume of space when I get an } \\
\text { explanation from the teacher or classmate with concrete props (pencil case, } \\
\text { rubric, and other box-shaped objects). }\end{array}$ \\
\hline & & No one person can help me learn to solve problems on volume-building problems. \\
\hline \multirow{5}{*}{$\begin{array}{l}\text { 3. Verbal } \\
\text { Persuasion }\end{array}$} & $\begin{array}{l}\text { A. Believe in being able to } \\
\text { complete difficult tasks if you } \\
\text { have the support of others }\end{array}$ & $\begin{array}{l}\text { 11. The teacher told me that I am a smart student in Math, this made me believe that I } \\
\text { can solve difficult building problems. }\end{array}$ \\
\hline & \multirow{3}{*}{$\begin{array}{l}\text { B. Confident of being able to } \\
\text { complete different tasks if you } \\
\text { get support from others }\end{array}$} & $\begin{array}{l}\text { 12. I am excited about studying the volume of rectangular prism and cubes when the } \\
\text { teacher explains their benefits. }\end{array}$ \\
\hline & & $\begin{array}{l}\text { 13. When a friend doesn't like the picture, I made of the combined rectangular prism } \\
\text { and cubes, it makes me lazy to make a better picture. }\end{array}$ \\
\hline & & $\begin{array}{l}\text { 14. What friends say when learning about the rectangular prism and cubes with } \\
\text { concrete objects such as pencil cases, rubrics, and other box-shaped objects is } \\
\text { useless making me lazy to study. }\end{array}$ \\
\hline & $\begin{array}{l}\text { C. Can confidently complete } \\
\text { challenging tasks if you have } \\
\text { the support of others }\end{array}$ & $\begin{array}{l}\text { 15. When my parents and friends talk about my work on rectangular prism and cubes, } \\
\text { it is an amazing work that makes me proud to make my next work in another } \\
\text { form. }\end{array}$ \\
\hline \multirow{9}{*}{$\begin{array}{l}4 . \\
\text { Psychologica } \\
\text { l Index }\end{array}$} & \multirow{2}{*}{$\begin{array}{l}\text { A. I'm sure I can complete a } \\
\text { difficult task if I'm feeling } \\
\text { good }\end{array}$} & $\begin{array}{l}\text { 16. I find it difficult when dealing with the difficult volume of cubes and rectangular } \\
\text { prism }\end{array}$ \\
\hline & & I feel comfortable discussing Student Worksheets with friends \\
\hline & \multirow{4}{*}{$\begin{array}{l}\text { B. I am sure that I can } \\
\text { complete different tasks if I } \\
\text { feel cheerful }\end{array}$} & $\begin{array}{l}\text { 18. I am desperate to be asked to solve story problems about geometry in everyday } \\
\text { life }\end{array}$ \\
\hline & & $\begin{array}{l}\text { 19. I believe that drawing a rectangular prism, it will make it easier for me to solve the } \\
\text { volume problem in everyday life first. }\end{array}$ \\
\hline & & $\begin{array}{l}\text { 20. I am interested in drawing two-dimensional objects from three-dimensional } \\
\text { objects if I see the object directly }\end{array}$ \\
\hline & & $\begin{array}{l}\text { 21. I am not sure I can work on volume problems if the cubes and rectangular prism } \\
\text { are combined }\end{array}$ \\
\hline & \multirow{3}{*}{$\begin{array}{l}\text { C. Confident of being able to } \\
\text { complete a challenging task } \\
\text { when my feelings are in a } \\
\text { happy state }\end{array}$} & $\begin{array}{l}\text { 22. I get nervous when the teacher gives me practice questions on cube and } \\
\text { rectangular prism combined }\end{array}$ \\
\hline & & $\begin{array}{l}\text { 23. I feel challenged to solve the problem of the cube volume and rectangular prism } \\
\text { story }\end{array}$ \\
\hline & & $\begin{array}{l}\text { 24. I was challenged to find various ways to calculate the volume of a cube and } \\
\text { rectangular prism }\end{array}$ \\
\hline
\end{tabular}




\section{Results}

\subsection{Early Mathematics Ability (EMA)}

Early Mathematics Ability became a benchmark for the classification of cognitive competencies of students. Early mathematical ability is the ability of students to understand the prerequisite material on the material to be taught later. Early abilities become an important part of subsequent cognitive abilities. Students who have required prior knowledge can follow and carry out subsequent learning [28]. The material tested was the volume of the cube and rectangular prism. Therefore, students must have the initial ability to support the resolution of the problem of the volume of cubes and rectangular prism such as indicators performing arithmetic calculations on number operations, calculating square roots, determining the area of flat shapes, calculating the measurement of length units, and solving problem-solving problems. The EMA problem for indicators performing arithmetic calculations was $7-4$ x $6: 2+8=\ldots$ This problem was the basis of students' ability to operate problem-solving on story problems that required good arithmetic skills. The matter of doing square root calculations for example $\sqrt{81} \times\left(\sqrt[3]{1}_{1000}-{ }^{3} \sqrt{125}\right)=\ldots$ The calculation of the square root became the foundation for solving the problem of the cube and rectangular prism volumes using cubic units and root operations. The related problem determined the area of the flat shape as follows: note the shape of the flat below, calculate the area of the following three shapes!

This problem served to illustrate the related understanding of identifying objects and their criteria according to the appropriate formula for calculating the volume of a cube and rectangular prism. Working on calculations of unit length measurements such as 10.000 $\mathrm{cm}+3 \mathrm{~km} \times 4 \mathrm{dm}-2 \mathrm{dam}=\ldots \mathrm{m}$, the problem illustrated the ability to transform units of length and volume in the volume of cube and the rectangular prism which had different units such as $\mathrm{dm}^{3}$ and liter. Next is the problem of resolving the problem solving on story questions like $\mathrm{Mr}$.
Adi that wants to make the front and back porch of his house 5 meters long and $3 \mathrm{~m}$ wide for the front porch and the back porch, measuring 3 meters on each side. What is the area of the two terraces? This problem demonstrates the ability to understand and solve problem-solving in story problems in solving the volume of cube and rectangular prism. The results of the EMA analysis became the standard EMA classification on the measurement of student SE achievement. The achievement of SE students was reviewed by EMA through the final average scale. Benchmark and Normative Grading was applied to students' SE criteria [29].

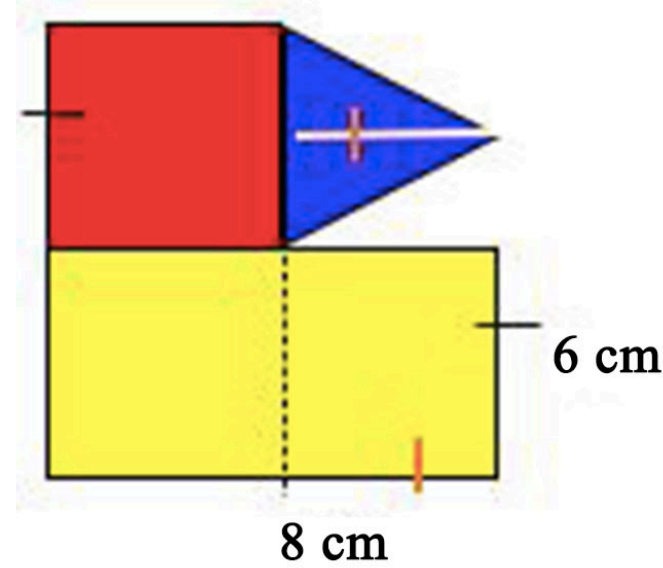

Figure 2. EMA's question of determining the area of flat shape

\subsection{Descriptive Analysis of Student's Self-efficacy Achievement Based on EMA}

The descriptive analysis served to describe the distribution of data related to the lowest scale, highest, average, and standard deviation of the SE scale and have been classified according to the reference value used. The recapitulation of SE achievement is reviewed by EMA contained in Table 3:

Table 3. Recapitulation of Self-Efficacy Achievement is reviewed by EMA

\begin{tabular}{|c|c|c|c|c|c|c|}
\hline Achievement & EMA & Coaching & Lowest Scale & Highest Scale & $\bar{x}$ & $S d$ \\
\hline \multirow{4}{*}{$\begin{array}{c}\text { Maximum Scale } \\
71\end{array}$} & \multirow{2}{*}{ High } & CPA & 36 & 62 & 51,49 & 7,62 \\
\cline { 3 - 8 } & \multirow{2}{*}{ Medium } & Conventional & 45 & 60 & 51,67 & 4,77 \\
\cline { 3 - 8 } & \multirow{2}{*}{ Low } & CPA & 33 & 71 & 53,36 & 9,23 \\
\cline { 3 - 8 } & & Conventional & 33 & 64 & 48,23 & 8,13 \\
\cline { 3 - 8 } & & CPA & 45 & 64 & 56,88 & 6,99 \\
\hline
\end{tabular}


Table 1 showed the achievement of SE students reviewed by the EMA who guided CPA higher than conventional guidance. Achievement of SE was reviewed by EMA with CPA guidance classified as moderate, except for the low EMA of the two groups categorized as high. Furthermore, the achievement of SE of EMA students was high with CPA guidance lower than the moderate and low EMA groups. Achievement of SE students in medium EMA with conventional guidance was lower than high and low EMA. The description emphasized that CPA guidance was more effective in developing SE students for each EMA than conventional guidance. SE of low EMA students with CPA guidance was more developed than high and medium EMA. Figure 3 clarified the difference in students' SE achievement based on the EMA:

\subsection{Inferential Analysis of Student's Self-efficacy Achievement based on EMA}

Inferential analysis functions to conclude mean differences significantly. Test the average difference using the t-test. Recapitulation of the average difference test reviewed by the EMA is being contained in Table 4 .

Information Table 2 p-value of achieving SE on high EMA was greater than 0.05 , thus achieving SE of students on high EMA with CPA guidance; there was no significant difference with students on conventional approaches. The achievement of SE EMA was moderate. The p-value is smaller than 0.05. Accordingly, the achievement of SE students in moderate EMA who are given CPA guidance was significantly better than students in conventional guidance. Achievement of low SE EMA above 0.05. In conclusion, low EMA achievement of SE students in CPA learning produced no significant difference with conventional guidance. Consequently, achieving SE students with CPA guidance did not differ significantly from conventional guidance, based on the EMA classification, unless the EMA is being. This proved the guidance of the CPA approach was more capable of developing self-efficacy in the EMA group than the conventional approach.

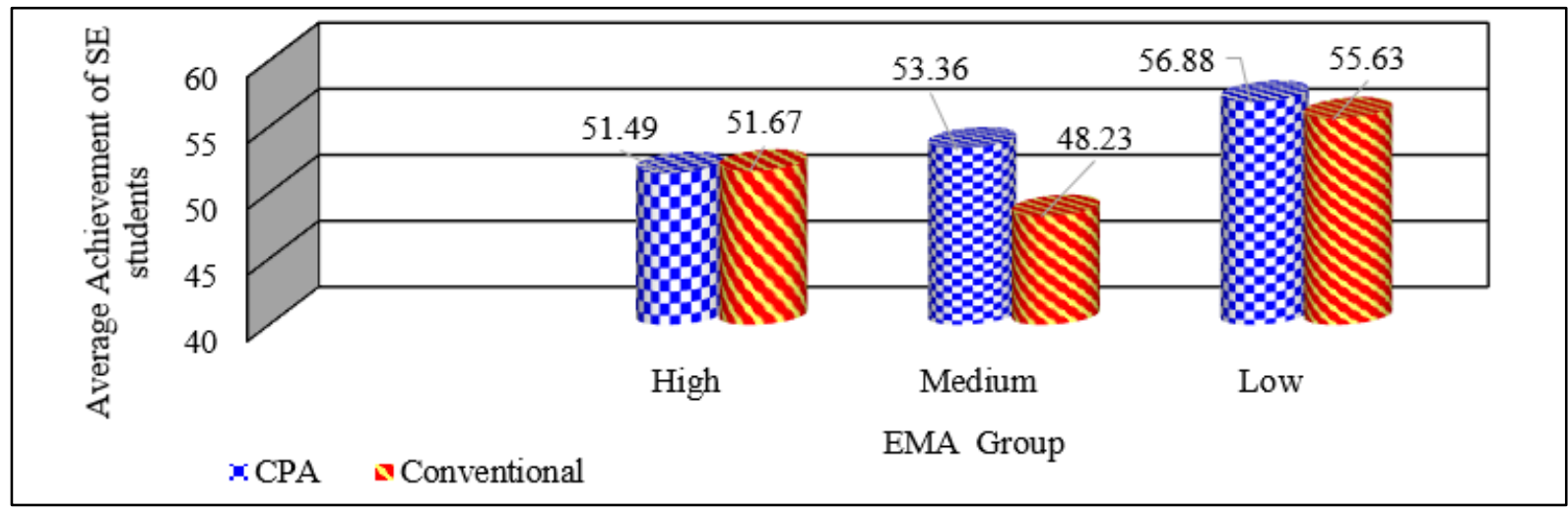

Figure 3. Average Achievement of Student Self-Efficacy

Table 4. Summary of Average Difference Test for Self-Efficacy Achievement is reviewed by EMA

\begin{tabular}{|c|c|c|c|c|c|c|c|c|}
\hline t-test & EMA & Coaching & Mean & $c_{\text {ount }}$ & $d f$ & $t_{\text {able }}$ & $p$-value & Note \\
\hline \multirow{6}{*}{ Maximum Scale $=71$} & \multirow{2}{*}{ High } & CPA & 21,6250 & \multirow{2}{*}{0,066} & \multirow{2}{*}{24} & \multirow{2}{*}{2,064} & \multirow{2}{*}{0,474} & \multirow{2}{*}{$\mathrm{H}_{0}$ accepted } \\
\hline & & Conventional & 21,7000 & & & & & \\
\hline & \multirow{2}{*}{ Medium } & СРA & 22.4118 & \multirow{2}{*}{2,525} & \multirow{2}{*}{71} & \multirow{2}{*}{1,994} & \multirow{2}{*}{0,007} & \multirow{2}{*}{$\mathrm{H}_{0}$ rejected } \\
\hline & & Conventional & 20,2564 & & & & & \\
\hline & \multirow{2}{*}{ Low } & $\mathrm{CPA}$ & 23,8889 & \multirow{2}{*}{0,403} & \multirow{2}{*}{18} & \multirow{2}{*}{2,101} & \multirow{2}{*}{0,346} & \multirow{2}{*}{$\mathrm{H}_{0}$ accepted } \\
\hline & & Conventional & 23,3636 & & & & & \\
\hline
\end{tabular}




\section{Discussion}

SE in medium EMA students was on the CPA guidance more developed than high and low EMA. The development of SE can also be seen in daily journals based on high, medium, and low EMA as presented in Figure 4 below:

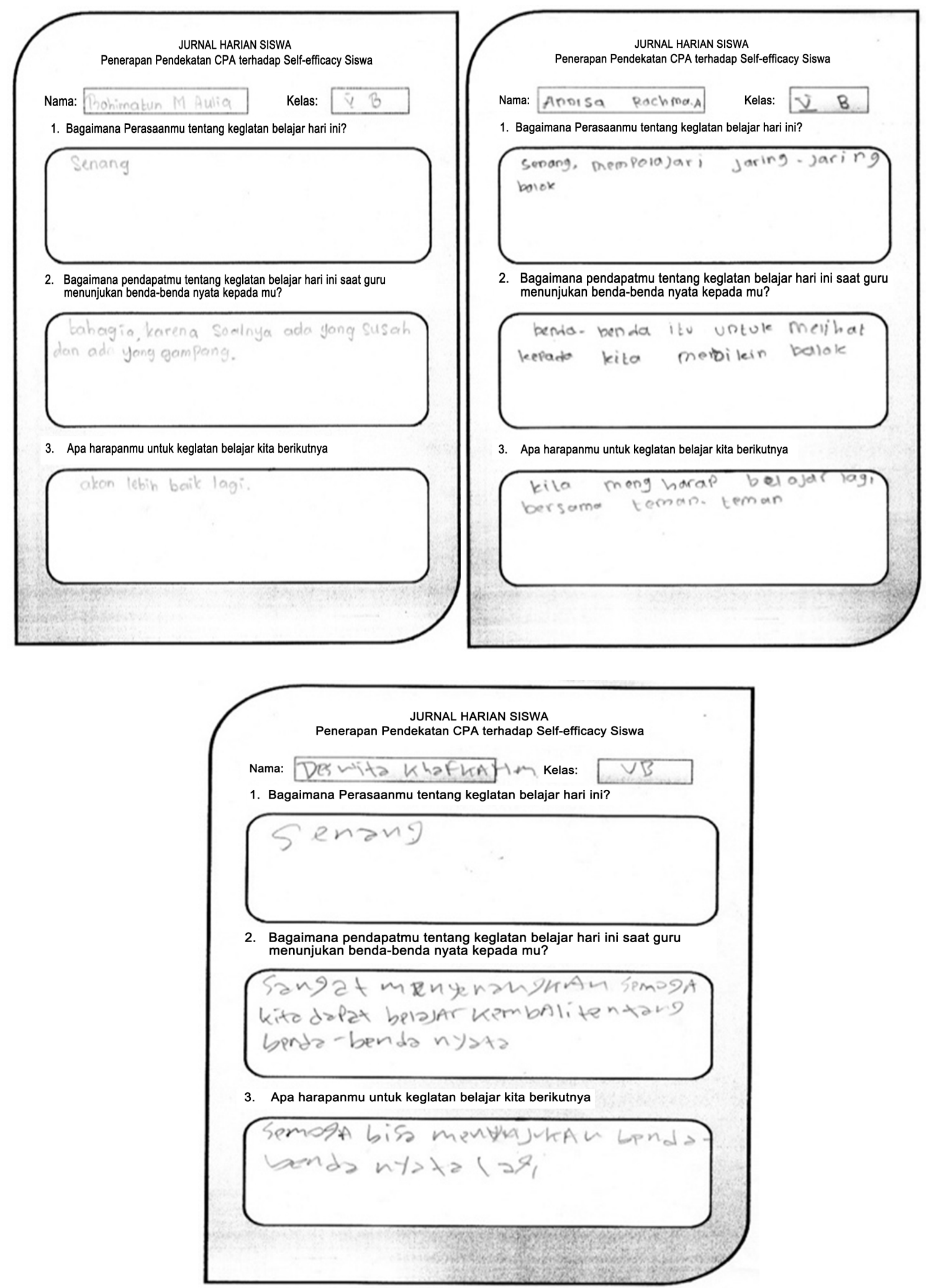

Figure 4. Student Daily Journal Based on High, Medium and Low EMA (Look from the Left to the Right, and Down) 
The meaning of figure 4 for the three daily journals of students in the high EMA group (left-top) above is:

1. How do you feel about today's learning activities? Student: Happy

2. How do you think about today's learning activities when the teacher showed you real objects?

Student: Happy, because the problem consists of difficult and easy questions

3. What are your hopes for the next activity? Student: It will be even better

The meaning of figure 4 for the students' EMA group's daily journal (right-top) above is:

1. How do you feel about today's learning activities? Student: Enjoyed studying the rectangular prism nets

2. How do you think about today's learning activities when the teacher showed you real objects?

Student: The objects are to show us how to make a rectangular prism

3. What are your hopes for the next activity?

Student: We hope to study again with friends

The meaning of figure 4 for the low EMA group students' daily journal (below) above is:

1. How do you feel about today's learning activities? Student: Happy

2. How do you think about today's learning activities when the teacher showed you real objects?

Student: It's great fun, hopefully, we can learn again about real things

3. What are your hopes for the next activity?

Student: Hopefully it can show real objects again

Figure 3 supported the findings of inferential statistics, daily journals inform discussion of heterogeneous small groups, and groups in CPA learning appeared to foster a sense of excitement and high learning enthusiasm. Growing happiness indicated that SE students develop in their psychological status. Students in these journals were challenged with easy to difficult questions, which means that SE students developed in the aspect of their personal success experience. Students also write down that they wished to learn with their friends to show aspects of the experience of the success of others developing. Activities centered at home, school, and the environment provide valuable experiences in social life [30]. The results of observations of medium and low EMA students were proven not much different, Figure 5 provides proof:

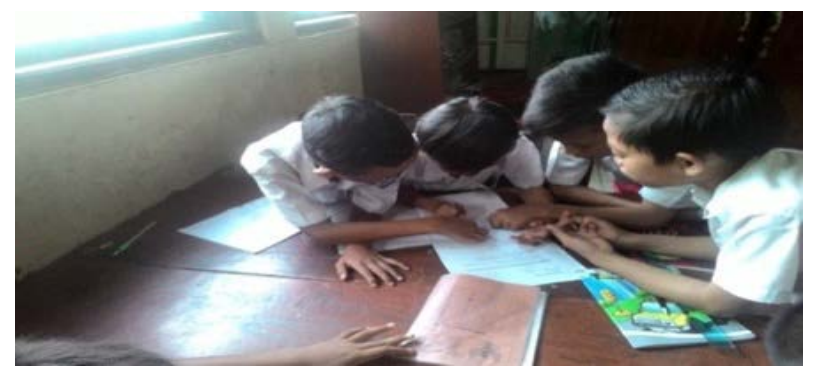

Figure 5. Student Discussion Activity Medium and Low EMA Groups
Students on CPA guidance were seen to be following the guidance well. The discussion was not dominated by high EMA students, medium and low EMA students also began to enthusiastically discuss and did presentations. High EMA students began to limit taking part in completing worksheets given because moderate and low EMA students began to play a role on the complete task. This means that students can determine their learning goals. SE is related to their own ability to organize and implement actions needed for their goals [31].

The results of this study were in line with several previous studies included. Likewise, students' mathematical SE achievement in generative learning was better than students in inquiry and conventional learning based on EMA [32]. Besides, the findings of students' SE achievement in mathematics after applying a realistic mathematics approach were better than before the learning was applied [33]. Furthermore, the transformative learning model was seen to develop students' SE to be better and increased in terms of student ability [34]. The study implied the scientific critical thinking model became an alternative to training SE students [35]. The study explains there was a significant difference in favor of the experimental group among the students' post-test scores of internal goal orientations, task values, and self-efficacy perceptions at public schools. As a result of the research, the Grid Model has proven that students with low socioeconomic levels have increased their motivation towards self-regulation and the students with high socioeconomic levels have continued their high motivation levels [36]. The last study informed both descriptive and inferential data analysis show that the improvement of students' SEM is better in students with CPA learning approach rather than students with conventional learning, seen as a whole and in every Mathematical Prior Ability [12]. Achievement of SE students through CPA guidance was more improved than conventional learning. This was the impact of the CPA approach giving opportunities for increasing SE aspects. This explanation was taken from the words of the American Institutes for Research that students who practice with concrete media developed mental representations more quickly and comprehensively showing high ambition and a good work attitude [37]. Concrete objects create fun manipulation for students, if students are happy, learning will be excited [20]. According to the study described, learning will be efficient if students felt happy, happy in learning made learning comfortable and enthusiastic. This is what drives student learning satisfaction so that learning motivation and confidence increased [38]. Supporting these findings aspects influenced by SE were learning outcomes [39]. Achievement of SE students who are classified as low EMA showed more development by CPA guidance. This was not surprising because the study said there was no correspondence between SE and cognitive levels of students, so students with high cognitive levels were not 
necessarily high SE, and vice versa [40]. In line with this, it was also found that there was no relationship between the SE of elementary school students and their mathematics learning outcomes [41]. Low-ability students always asked and reviewed their assignments, especially for difficult tasks. Students were aware of learning disabilities if they have a low SE level, especially regarding the complex use of mathematics [42]. That was what created the lower EMA SE more developed. Other factors that cause students with low self-efficacy to develop more or there are significant differences after being given CPA guidance include being able to follow the learning stage little by little and systematically through the manipulation of concrete objects, represent objects and apply them with mathematical symbols according to cognitive abilities. At the beginning of learning, low EMA students choose to be silent and passive in learning because they focus on observing the learning process being carried out. This is evident in Figure 6 below:

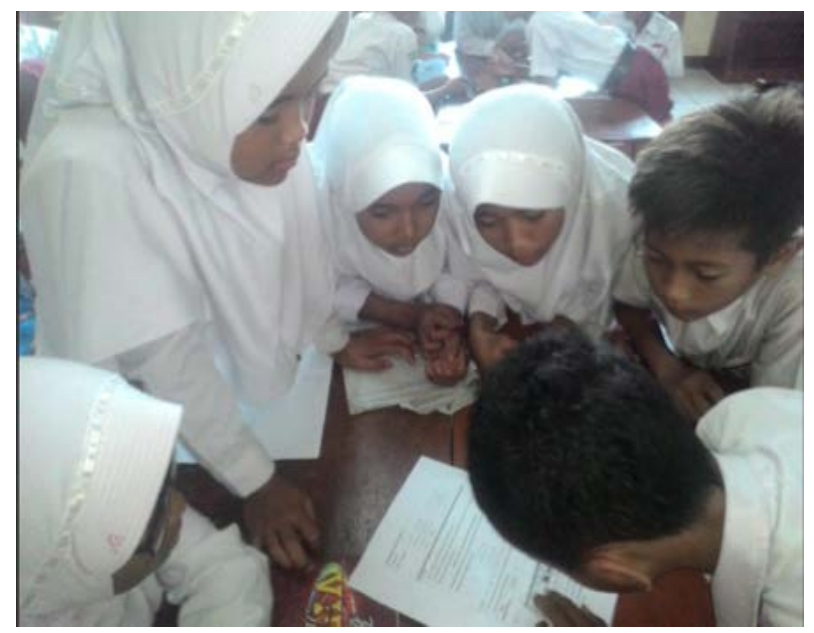

Figure 6. Students with low EMA make observations more intensively

Also, after they observe intensively all the learning processes, they diligently work on the assignment given and actively ask the teacher, this certainly makes their SE develop through learning the abilities of others and interacting with the teacher to ask questions about the problems at hand, thus aspects authentic experiences, and the experiences of others they develop.

These results informed EMA not to determine the SE level. Other findings reinforced that there was no significant interaction of teaching and previous mathematics ability levels on students' SE mathematics [43]. The findings of the achievement of SE students with high and moderate EMA seen no significant difference between CPA and conventional guidance. It means that the development of SE EMA with high and moderate criteria is even still limited. Students with high SE found it difficult to evaluate, create conceptual and procedural knowledge [44]. The reason is that high and moderate EMA students have intelligence that is not much different when viewed based on the results of each EMA. This affects his personal experience of prior knowledge; the motivation that is not much different when learning. They have the same low SE because they tend to get bored quickly with multi-stage guidance. The students prefer conventional learning which directly refers to the abstraction process, as well as the development of their social experiences that always dare to discuss with friends or teachers about the lessons they have mastered or directly provide evidence, as this can be seen in Figure 7 where students with high and moderate EMA have the courage to prove the components of the rectangular prism:

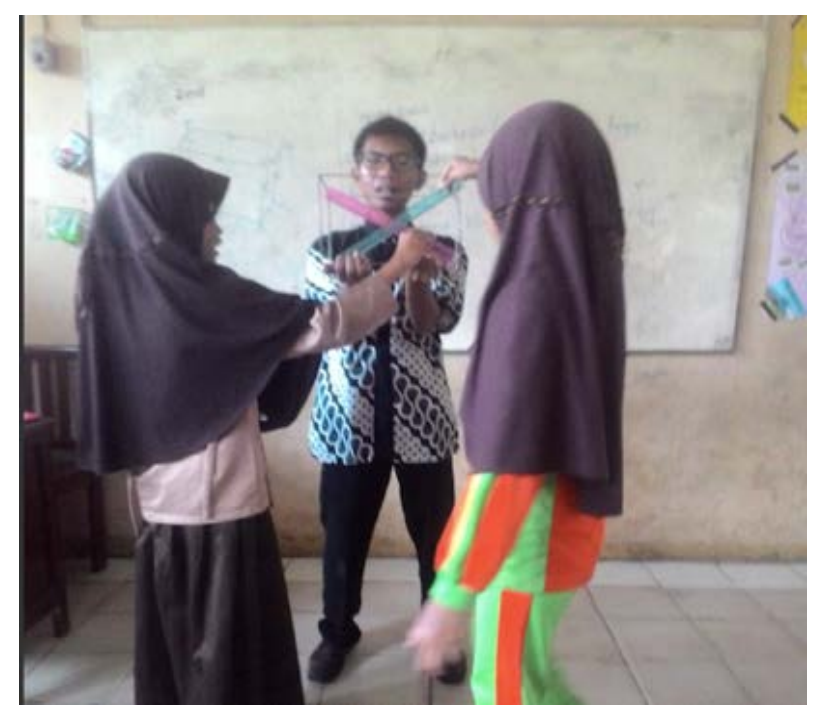

Figure 7. Students with EMA (high and medium) defiance to prove

Based on the findings on the SE indicator, it was found that the aspect where the best achievement occurred appeared in aspect 4, namely the psychological index which was detailed in statements $16,17,18,19,20,21,22$, 23 , and 24, whereas the aspect experiencing the worst achievement appears in aspect 1 , namely personal experience in detail occurs in statements 1,2, 3, 4, and 5 . Thus, personal experience is not a factor that greatly affects student SE, especially in students with high and moderate EMA groups who have excellent personal experience with prior knowledge. While the psychological index aspect appears as the aspect that has experienced the best achievement, the psychological index is considered to be a very influential factor through the process of concrete manipulation, students with low EMA will feel happy and learn gradually according to their cognitive development. This reason also resulted in differences in achievement in the SE of the low EMA group. The use of manipulative objects must be planned as carefully as possible before they are implemented so that they give a positive effect. Research suggests planning, implementing, and evaluating efforts to increase science participation among students should consider how to develop more scientific efficacy and positive attitudes towards subjects [45]. Moreover, CPA learning is more seen to develop the achievement of indicators, because only indicators $2 \mathrm{c}, 4 \mathrm{~b}$, and $4 \mathrm{c}$ were 
more developed with conventional guidance. The indicator that has the highest achievement is indicator 4a, which is the confidence that you can complete a difficult task when you are happy, On these indicators, it can also be seen that CPA learning is higher than conventional learning, This also made students with low EMA more able to develop their SE because they learn happily and gradually with concrete manipulations, and vice versa, at high and medium EMA students feel bored because the learning process is very wordy. Meanwhile, the indicator experiencing the lowest achievement is well-grounded in indicator 2a, which is the belief that you can complete a difficult task if other people can complete it. In this indicator, it can also be seen that CPA learning and conventional learning have a scale that is not much different. In full, it is presented in the diagram in Figure 8 below.

\section{Conclusions}

Achievement of SE students with CPA guidance was better than conventional mentoring in EMA review. The
SE achievement of students in the high and moderate EMA groups did not show a significant difference because they preferred direct learning that did not go through many stages. The SE achievement of students with low EMA is more developed because they are facilitated to learn according to their cognitive stages through a process of concrete manipulation and a feeling of pleasure representing the object being studied. Before guiding CPA, teachers needed to strengthen the plan that was designed comprehensively in the scenario before implemented. The development of students' SE using the CPA and conventional approaches was still relatively low and moderate, including several factors such as time management, process, and evaluation of learning. The researchers recommend developing other mathematical attitudes with longer periods so that the affective students can develop well. CPA guidance proposed to learn opportunities through concrete objects that made learning more real and could develop students' SE. Thus, the CPA approach became an alternative in mathematics learning especially in developing students' affective.

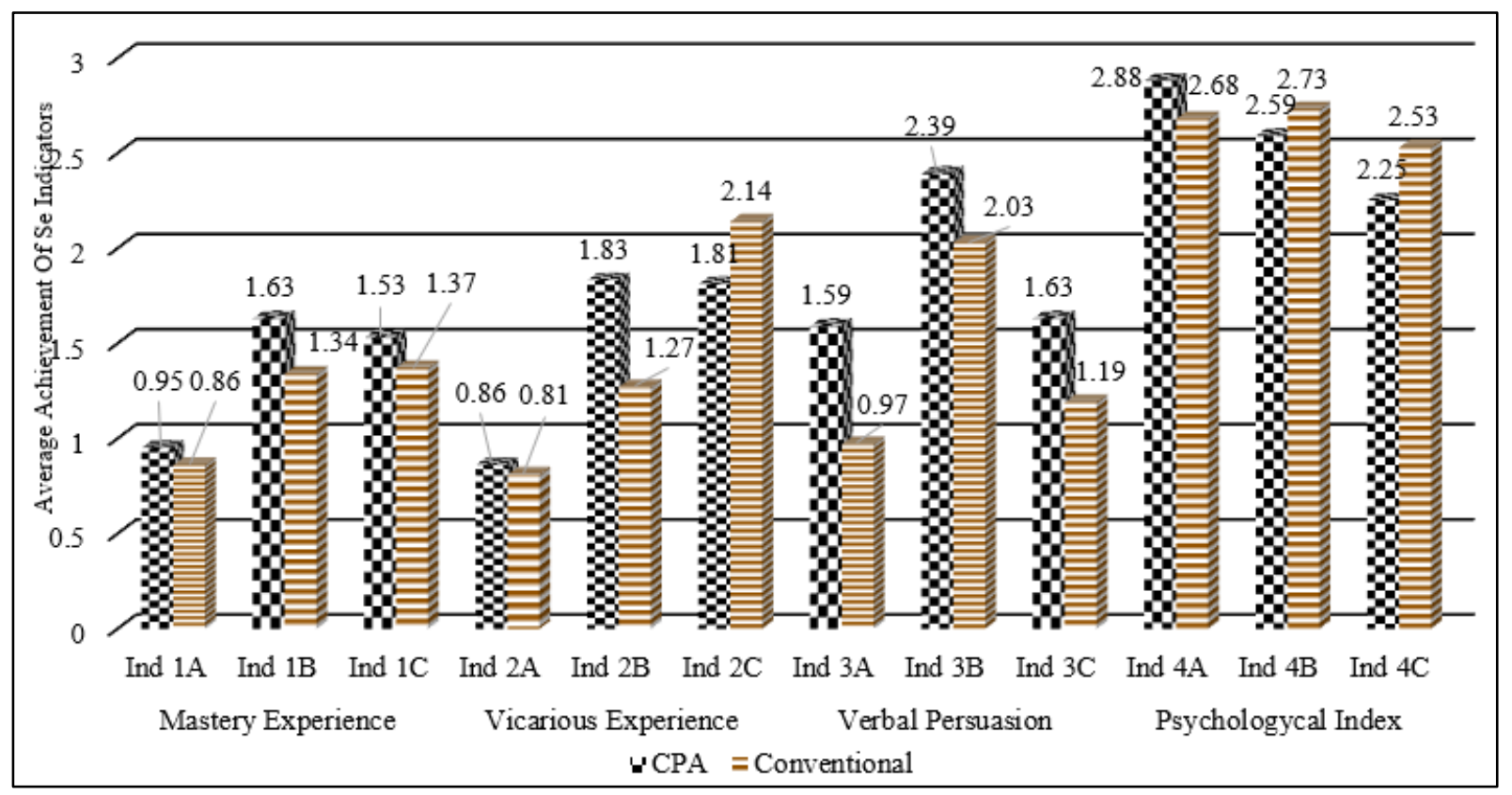

Figure 8. Achievement of Self-efficacy based on indicators 


\section{REFERENCES}

[1] A. Bandura, "Self-Efficacy,” Encycl. Hum. Behav., vol. 4, pp. 71-81, 1994.

[2] F. D. Utari, Maridi, and B. Sugiharto, "Peningkatan Hasil Belajar dan Academic Self-Efficacy Siswa Melalui Model Pembelajaran Problem Based Learning (PBL) pada Kelas X 1A-4 SMA Batik 1 Surakarta Tahun Pelajaran 2013/2014,” J. Pendidik. Biol., vol. 7, pp. 101-112, 2015.

[3] M. P. I. Susanti and A. S. Siwi, "Relationship of Self-Efficacy on Diabetes Mellitus Type 2 to Self-Management Behavior in Sumbang 1st Health Center, Banyumas Regency,” in 1st International Conference on Community Health (ICCH 2019), 2020, vol. 20, no. Icch 2019, pp. 160-163, doi: https://dx.doi.org/10.2991/ahsr.k.2 00204.036

[4] M. Yüksel, N. Okan, Z. Eminoğlu, and D. Akça-Koca, "The mediating role of self-efficacy and hope on primary school students' social-emotional learning and primary mental abilities,” Univers. J. Educ. Res., vol. 7, no. 3, pp. 729-738, 2019, doi: 10.13189/ujer.2019.070312.

[5] İ. G. Cetinkaya and F. Y. Tilfarlioğlu, "Three Factors Affecting Language Learning: Grammar Learning Strategies, Self-efficacy, and Learner Autonomy,” Univers. J. Educ. Res., vol. 8, no. 7, pp. 2929-2936, 2020, doi: 10.13189/ujer.2020.080721.

[6] S. Valente, A. Veiga-Branco, H. Rebelo, A. A. Lourenço, and A. M. Cristóvão, "The relationship between emotional intelligence ability and teacher efficacy,” Univers. J. Educ. Res., vol. 8, no. 3, pp. 916-923, 2020, doi: 10.13189/ujer.2020.080324.

[7] M. R. Muthohhar, Supardi, and P. D. Yulianti, "Hubungan Antara Self Efficacy dengan Perilaku Menyontek Siswa MTs Masalikil Huda Tahunan Jepara,” Quanta, vol. 3, no. 3, pp. 90-100, 2019, doi: 10.22460/q.v1i1p1-10.497.

[8] R. I. Putri and R. H. Santosa, "Keefektifan Strategi React Ditinjau Dari Prestasi Belajar, Kemampuan Penyelesaian Masalah, Koneksi Matematis, Self Efficacy,” J. Ris. Pendidik. Mat., vol. 2, no. 2, p. 262, 2015, doi: 10.21831/jrpm.v2i2.7345.

[9] Kemendikbud, Peraturan Menteri Pendidikan dan Kebudayaan Republik Indonesia Nomor 21 Tahun 2016 tentang Standar Isi Pendidikan Dasar Dan Menengah (Salinan). Jakarta: Kementerian Pendidikan dan Kebudayaan RI, 2016.

[10] National Research Council, Adding It Up. Washington, DC: National Academy Press, 2001.

[11] A. H. Kaluge, "Metacognition, self-efficacy, and mathematics learning achievement: A study based on gender differences,” J. Phys. Conf. Ser., vol. 1375, no. 1, 2019, doi: 10.1088/1742-6596/1375/1/012012.

[12] H. E. Putri, A. Yuliyanto, G. Nikawanti, P. Rahayu, and N. Majid, "Concrete pictorial abstract approach to the improvement of elementary school students' self-efficacy mathematics,” Int. Conf. Math. Sci. Educ. Univ. Pendidik.
Indones., vol. 4, pp. 25-31, 2020.

[13] H. E. Putri, M. A. Wahyudy, A. Yuliyanto, and F. Nuraeni, "Development of Instruments to Measure Mathematical Anxiety of Elementary School Students," Int. J. Learn. Teach. Educ. Res., vol. 19, no. 6, pp. 282-302, Jun. 2020, doi: 10.26803/ijlter.19.6.17.

[14] J. D. Dagdag, O. C. A. Jr, R. P. Salviejo, J. F. Pascual, and J. M. H. Dagdag, "Development of Problem-Solving Efficacy Scales in Mathematics," Univers. J. Educ. Res., vol. 8, no. 6, pp. 2397-2405, 2020, doi: 10.13189/ujer.2020.080624.

[15] A. Bandura, Self-Efficacy: The Exercise of Control. New York: W.H. Freeman and Company, 1997.

[16] U. Toharudin, A. Rahmat, and I. S. Kurniawan, "The important of self-efficacy and self-regulation in learning: How should a student be?,” J. Phys. Conf. Ser., vol. 1157, no. 2, 2019, doi: 10.1088/1742-6596/1157/2/022074.

[17] A. Yuliyanto, T. Turmudi, M. Agustin, H. E. Putri, and I. Muqodas, "The Interaction Between Concrete-Pictorial-Abs tract (CPA) Approach and Elementary Students' Self-Efficacy In Learning Mathematics,” Al Ibtida J. Pendidik. Guru MI, vol. 6, no. 2, p. 244, Oct. 2019, doi: 10.24235/al.ibtida.snj.v6i2.5226.

[18] R. W. Bybee, Piaget for Educators. Columbus: Charles E. Merrill Publishing Company, 1982.

[19] R. W. Dahar, Teori-teori Belajar \& Pembelajaran. Jakarta: Erlangga, 2011.

[20] H. E. Putri and I. Muqodas, Pendekatan Concrete-Pictorial Abstract (CPA), Kecemasan Matematis, Self-Efficacy Matematis, Instrumen dan Rancangan Pembelajarannya. Sumedang: UPI Sumedang Press, 2019.

[21] Darmansyah, Strategi Pembelajaran Menyenangkan dengan Humor. Jakarta: Bumi Aksara, 2011.

[22] M. L. Choi, “The analysis of museum education trends based on educational policy - The development of museum education model in accordance with the free semester system,” J. Museum Stud., vol. 35, pp. 63-88, 2018.

[23] I. N. Yenti and Y. S. Kusumah, "Source of Self-Efficacy for First-Year College Students Based on Gender and Prior Knowledge,” J. Phys. Conf. Ser., vol. 1554, p. 012053, 2020, doi: 10.1088/1742-6596/1554/1/012053.

[24] W. Morgan and M. Streb, "Building Citizenship: How Student Voice in Service-Learning Develops Civic Values," Soc. Sci. Q., vol. 82, no. 1, pp. 154-169, Mar. 2001, doi: 10.1111/0038-4941.00014.

[25] S. Oktaviani, B. Santoso, and C. Hiltrimartin, "Penggunaan Powerpoint Game pada Pembelajaran Lingkaran di Kelas VIII SMP Negeri 1 Tanjung Raja,” J. Pendidik. Mat., vol. 11, no. 1, pp. 29-43, Jan. 2017, doi: 10.22342/jpm.11.1.4131.29-42.

[26] A. Yuliyanto, A. Fadriyah, K. P. Yeli, and H. Wulandari, "Pendekatan Saintifik untuk Mengembangkan Karakter Disiplin dan Tanggung Jawab Siswa Sekolah Dasar,” Metod. Didakt., vol. 13, no. 2, pp. 87-98, Jan. 2018, doi: 10.17509/md.v13i2.9307.

[27] S. Prabawanto, "The enhancement of students ' mathematical problem solving ability through teaching with 
metacognitive scaffolding approach," in Mathematics, Science, and Computer Science Education (MSCEIS 2016), 2017, vol. 040014, pp. 1-6, doi: 10.1063/1.4983952.

[28] E. Z. Jamaan, D. N. Musnir, and Z. Syahrial, "The effect of problem-based learning model on students' geometry achievement by controlling mathematics initial ability," $J$. Phys. Conf. Ser., vol. 1554, no. 1, 2020, doi: 10.1088/1742-6596/1554/1/012034.

[29] E. Suherman and Y. S. Kusumah, Petunjuk Praktis untuk Melaksanakan Evaluasi Pendidikan Matematika. Bandung: Wijayakusumah 157, 1990.

[30] H. C. Hunt, Becoming an Educator: An Instruction by Specialists to The Study and Practice of Education. Boston: Houghton Mifflin Company, 1963.

[31] D. Arias-Chávez, T. Ramos-Quispe, K. O. Villalba-Condori, and J. E. Postigo-Zumarán, "Academic procrastination, self-esteem, and self-efficacy in first-term university students in the city of Lima," Int. J. Innov. Creat. Chang., vol. 11, no. 10, pp. 339-357, 2020.

[32] Risnanosanti, “Kemampuan Berpikir Kreatif Matematis dan Self-efficacy Terhadap Matematika Siswa Sekolah Menengah Atas (SMA) dalam Pembelajaran Inkuiri," Universitas Pendidikan Indonesia, 2010.

[33] P. Arifin, B. N. Trisna, and M. F. Atsnan, "Mengembangkan Self-Efficacy Matematika Melui Pembelajaran Pendekatan Matematika Realistik pada Siswa Kelas VII D SMP Negeri 27 Banjarmasin Tahun Pelajaran 2016-2017,” Math Didact. J. Pendidik. Mat., vol. 3, no. 2, pp. 93-104, 2017.

[34] I. R. D. Nur and D. Firmansyah, "The use of transformative learning in developing students' self-efficacy,” J. Phys. Conf. Ser., vol. 1315, no. 1, 2019, doi:10.1088/1742-6596/1315/1 /012057.

[35] Rusmansyah, L. Yuanita, M. Ibrahim, Isnawati, F. Rizkiana, and A. E. Kusuma, "Effect of scientific critical thinking model to train critical thinking skills and student self-efficacy,” J. Phys. Conf. Ser., vol. 1422, no. 1, 2020, doi: 10.1088/1742-6596/1422/1/012015.

[36] N. K. Abu and M. Gökdere, "The Effect of Differentiated Science Curriculum on Students' Motivational Regulations," Univers. J. Educ. Res., vol. 6, no. 3, pp. 455-465, Mar. 2018, doi: 10.13189/ujer.2018.060312.
[37] H. E. Putri, “The Influence of Concrete Pictorial Abstract (CPA) Approach to The Mathematical Representation Ability Achievement of The Pre-service Teachers at Elementary School,” Int. J. Educ. Res., vol. 3, no. 6, pp. 113-126, 2015.

[38] Sapar, A. Alfian, Isriami, M. V. I. Herdjiono, and Jusni, "The application of documentary film in improving student interest: An alternative for environmental education," IOP Conf. Ser. Earth Environ. Sci., vol. 343, p. 12156, 2019, doi: 10.1088/1755-1315/343/1/012156.

[39] A. J. Sundah, "Adlerian group counselling to improve student's self-efficacy,” Int. J. Innov. Creat. Chang., vol. 5, no. 5, pp. 136-147, 2019.

[40] W. K. H. W. Putri and S. Prabawanto, "The analysis of students' self-efficacy in learning mathematics,” J. Phys. Conf. Ser., vol. 1157, no. 3, 2019, doi: 10.1088/1742-6596/1157/3/032113.

[41] A. Yuliyanto, Turmudi, M. Agustin, I. Muqodas, and H. E. Putri, "The Relationship of Self Efficacy With Student Mathematics Learning Outcomes Through The Concrete-Pictorial-Abstract (CPA) Approach in Primary Schools,” JPSd J. Pendidik. Sekol. Dasar, vol. 6, no. 1, pp. 1-14, 2020, doi: http://dx.doi.org/10.30870/jpsd.v6i1.7213.

[42] Z. Ardi et al., "Exploring the elementary students learning difficulties risks on mathematics based on students mathematic anxiety, mathematics self-efficacy and value beliefs using rasch measurement," J. Phys. Conf. Ser., vol. 1157, no. 3, 2019, doi: 10.1088/1742-6596/1157/3/032095.

[43] S. Prabawanto, “The enhancement of students' mathematical self-efficacy through teaching with metacognitive scaffolding approach,” J. Phys. Conf. Ser., vol. 1013, no. 012135, 2018, doi: 10.1088/1742-6596/1013/1/012135.

[44] R. D. E. Prismana, T. A. Kusmayadi, and I. Pramudya, "Analysis of difficulties in mathematics problem solving based on revised Bloom's Taxonomy viewed from high self-efficacy,” J. Phys. Conf. Ser., vol. 1008, no. 1, 2018, doi: 10.1088/1742-6596/1008/1/012063.

[45] T. B. T. Ahmad, M. S. Nordin, M. B. Ibrahim, and E. S. Abulibdeh, "Drivers of Secondary School Students' Intention to Enrol in Science Studies," Univers. J. Educ. Res., vol. 7, no. 10A, pp. 42-47, Oct. 2019, doi: 10.13189/ujer.2019.071708. 